[Penetito, W. (2009). Place-Based Education: Catering for Curriculum, Culture and Community. New Zealand Annual Review of Education, 18, 5-29]

\section{Place-Based Education: Catering for Curriculum, Culture and Community ${ }^{1}$}

\section{WALLY PENETITO}

\section{Abstract:}

Place-based education (PBE) is not an overly familiar term in the New Zealand education context but it has a rapidly developing profile within the United States and parts of Canada, mainly as an outreach of the environmentalist movement. At the practical level "place-based education" sets out to answer two fundamental questions: "What is this place?" and "What is our relationship with it?" It is hypothesized that the New Zealand education system (including its students, teachers, learning institutions and curriculum) is seriously remiss in not providing adequate structured opportunities for all New Zealanders to have a consistent and long-term ontological identification with what Geoff Park (1996, p. 323) refers to as "the two cosmologies - the two landscapes" that co-exist in New Zealand. This article explores some of the theories and practices embedded in a place-based education for Aotearoa New Zealand and recommends a set of principles for advancing the practice. Areas of research are suggested as appropriate starting points for tertiary institutions.

$I^{2}$ 2004 the New Zealand Association for Research in Education Conference chose "turning the kaleidoscope" as its theme for the year. The kaleidoscope has always been a magical thing for me. You look through this little window at one end and see all these wonderful colours and patterns and as you turn it everything seems to fall and new colours and patterns emerge, just like magic. As the world becomes increasingly scientific, technological and secular-oriented, it is important that all those in education - teachers, administrators, managers, researchers, and policy writers - should endeavour to keep a healthy supply of imagination, craft and magic in their work. Why? Because education is like that. In its deepest sense it is a blending together of science with imagination, technology with craft, and the secular with the magical. Place-based education appeals to me as an ideally suited educational agenda for now and for the future because of its reliance on the integration of all these elements to imbue in each student the wonder of learning.

Much of the literature on place-based education (PBE) arises out of the work by teachers and researchers with indigenous peoples as much as with those interested in exploring the physical environment. ${ }^{2}$ As a consequence, the purposes underlying PBE are often intended to satisfy indigenous peoples' aspirations in education as a priority, but in every case, the objectives and strategies recommended are offered as being of direct benefit to everybody. ${ }^{3}$ A second important category of literature on $\mathrm{PBE}$ revolves around issues of ecological literacy, ${ }^{4}$ community studies, ${ }^{5}$ the specific relationship between place and space, ${ }^{6}$ the relationship between place and identity, ${ }^{7}$ and the politics involving biotechnology and biodiversity.

Research into PBE investigates areas that are often ignored, and raises questions that are often left unanswered because the tradition in research as it is in the theory, policy and practice of education in New Zealand, and elsewhere, is to concentrate on what works for the mainstream and then consider how non-mainstream groups compare with the mainstream. ${ }^{9}$ The education of Māori becomes a problem to the extent that solutions are only solutions if they are seen to correlate with the extent of "fit" with the deep cultural assumptions that provide the conceptual and moral legitimacy of mainstream education.

Some of the main themes in PBE include: environmental studies, ecological studies, biodiversity, community education, schoolcommunity relations, local history, and sustainable development. The emphasis of this article is not intended as support for the "Green Party" nor is it especially aligned to the interests of the "Māori Party". I want to emphatically address my concerns to the ordinary and routine in the whole education system. To most of us the ordinary and routine are invisible, taken for granted because they are ordinary and routine. In that insightful little book, Teaching as a Subversive Activity, Postman and Weingartner (1971) tell us how to deal with the ordinary and routine. "In order to get people to change something," they say, "you have to get them to think about it. In order to get them to think about it, you have to make it visible to them. One way to make the ordinary visible, curiously enough is to subtract it or interrupt it." My concern is to make a compelling case for all educational institutions within the compulsory sector to grasp the principles and practices of PBE and to design and implement programmes that are consistent with this philosophy. 


\section{This is Not $M$ ori/Indigenous Education, it is Education}

Two short stories (Story A and Story B) will suffice as an introduction to the concept of "spatial metaphors". We will then explore the meanings behind two forms of spatial metaphor, "who am I" which refers to a "politics of identity", and "where am I" which is about a "politics of location". A third story (Story C) is a personalised spatial metaphor, or pepeha in Māori terms. The questions the pepeha answers are, "What is this place and how do we fit into it?" Some essential characteristics of PBE include: ${ }^{10}$

(a) it emerges from the particular attributes of a place. The content is specific to the geography, ecology, sociology, politics, and other dynamics of that place;

(b) it is inherently multi-disciplinary and often promotes team teaching among educators and community resource people;

(c) it is inherently experiential. In many programmes this includes a participatory action or service learning component; and

(d) it connects place with self and community. Because of the lens through which place-based curricula are viewed, these connections are pervasive. These curricula include multi-generational and multicultural dimensions as they integrate with community resources.

These characteristics envision a purpose of education that is always present but often only in a tacit sense. It is timely that this purpose be made explicit. From a Màori point of view the relationship between the unhappy experience of schooling for a disproportionately large part of that population is screaming out for attention. The Māori-medium movement (kohanga reo, kura kaupapa Māori, wharekura and wānanga) is an absolutely essential component of Māori education provision but indications are it will remain secondary to the mainstream because most Māori attend mainstream institutions. Whether this is by choice or because of a lack of access to the alternative is not known. There is a clear link, I will argue, between problems of spatiality (identity and location) within mainstream education, to which the philosophy and practice of place-based education is a solution. At the end of the article I will frame the questions and define the issues to be researched under two themes: (a) what differences matter; and (b) how to make a difference in education for Aotearoa New Zealand.
The topic of this article has slowly penetrated my consciousness over the last few years with opportunities I have had to work with other indigenous scholars, mainly from Alaska, Hawai'i, the Pacific and Australia. The terminology of PBE comes from them. Over time I have become critically aware of the continuity between indigenous PBE and Māori education (Penetito, 2003). From my own uneventful days in primary, intermediate and secondary schools I know that what we learned about the place we call home was negligible. At primary school I learned about Josiah Clifton Firth who acquired 55,000 acres at Matamata in the 1860 s to 80 s. We also learned that Firth was on very friendly terms with Wiremu Tamihana Tarapīpipi of Ngāti Hauā. Strangely, we did not learn that Wiremu Tamihana was the son of Te Waharoa. What is spectacular about these omissions is that the school we were all attending when these stories were being told to us was Waharoa School in the village of the same name, surrounded by farms that were once the property of Firth and before him, Ngāti Hauā, with the pa of Te Waharoa and Tamihana a few miles down the road. We could ask, of course, why we didn't learn about these matters at home or on the marae. The only answer I have is a sad reflection on the relationship between school and the home of many Māori children. For some inexplicable reason most of us thought our parents were educationally ignorant. When they told us the teacher was wrong about Te Rauparaha or Te Kooti being savages and bad men we argued with them and said, "You don't know. You didn't go to school."

I suspect not much has changed with regard to what we know about the soil under our feet and the social history that is all around us. In what follows, seven themes are used to explore this proposition.

\section{Theme 1: Short Stories}

\section{Short Story $A$}

Something has happened in New Zealand over the last couple of years. More precisely, something has happened to Kiwis over the last couple of years. Spontaneous outbursts of "Ka mate! Ka mate!" at the Olympics in Greece; the launching of a Māori television channel in Auckland; Pākehā television news announcers opening and closing procedures with greetings and farewells in te reo Māori. There are the faces of Māori reporters across the board, leading, commenting and critiquing a variety of television programmes; the Māori production on stage and on television of Te Tangata Whai Rawa o Weneti (The Merchant of Venice); 
and then there's the internationalisation of the Ngāti Porou story of Paikea and the Whale. This completes Short Story A.

\section{Short Story B}

In an article in a local newspaper (Patterson, 2004) was the story of a polluted stream. "Too warm to support fish" was the heading. It was a report about a research project that examined the effects of pollution on fish in the Waikato, Tarawera, the Cam and Styx rivers in Canterbury, and the Waiwhetu Stream in Lower Hutt. "Of the five", the report states, "the Waiwhetu Stream was the most degraded." A month earlier the Greater Wellington regional council reported that eels found in the upper part of the stream contained 20 times the guideline level of DDT, while mussels found near the mouth of the river contained high levels of cobalt and lead.

In the same newspaper in September 2004, the heading ran, “New Zealanders demand a clean, ecologically sound environment while producing a huge amount of waste" (Your Voice, 2004). It was then reported, that: "In one year, for every person in Wellington city, 621 kilograms of rubbish is dumped, $55 \mathrm{~kg}$ of recyclable waste is collected, and $97 \mathrm{~kg}$ of sewage sludge is produced.... New Zealanders throw away almost four million tonnes of rubbish each year. By mass that's the equivalent of 1,000 buses a day. Sixty-five percent of it could be recycled or composted."

Both stories incorporate what are called "spatial metaphors". Story A can be interpreted in terms of a "politics of identity" and asks "who am I", while Story B displays a "politics of location" and asks the question "where am I?" The notion of politics suggests questions regarding contestation, power relations, and negotiation. Who I am and where I am are socially constructed phenomena but that does not deny what Harvey argues is, "their ultimate embeddedness in the materiality of the world" (1996, p. 211).

\section{Theme 2: Spatial Metaphors}

Various well-known spatial metaphors are introduced to illustrate their familiarity across cultures, over time and place. Each is alsoidiosyncratic in what is being said about a sense of belonging.

The first is, "I come from a little place in the middle of nowhere, the 'wopwops', the 'boondocks', the 'never-nevers' but to me it is the centre of the universe." This is the sort of statement heard quite often, certainly in Māori circles, but one should not be fooled by the apparent demeaning language used to describe remote rural places; the speaker is quite serious when $\mathrm{s} / \mathrm{he}$ says "but to me it is the centre of the universe." According to the eminent geographer Yi-Fu Tuan (2003, p. 150), "The centre is not a particular point on the earth's surface, it is a concept in mythic thought."

The second is, "It ain't where you're from, it's where you're at." This quote is from Paul Gilroy (1993, p. 120) who has several publications on the politics of black cultures, capitalism and race. The statement probably represents the voice of the diaspora.

The third, with apologies to Robert Burns is a toast and goes, "Here's tae us whas like us, damn few an' their a'deid." There is no attempt at avoidance of ethnocentrism in this celebration. Sassenachs present are definitely meant to feel uncomfortable.

The fourth is, "God save the squire and his relations and keep us in our proper stations." This nice little ditty probably has its origins at the time of the divine right of kings. In modified form its sentiments have survived the 19th and 20th century oligarchs and the megalithic international corporations of the 21st century.

The fifth is a very well known whakataukī or proverb among Māori, E kore koe e ngaro, he kakano i ruia mai i rangiätea. The translation reads, "You will never die out, the seed sown from Rangiātea." This is a comforting saying so long as you are descended from Rangiātea, that is, if you are Māori.

The sixth of our spatial metaphors is a quote from Simone Weil, "What does it mean to know one's place - a place not determined by geography or genealogy but by contingency, ethics, and thoughtful choice" (cited in Willinsky, 1998, p. 388). Simone Weil died in the 1950s. She was a French-Canadian scholar who relentlessly pursued what it meant to know a place as one's own. Immigrants know what this is about, that is, what it feels like to be out of place but no one experiences out of place more sharply than those who are colonised. The indigenous or tangata whenua of New Zealand who are out of place because of colonialism may well have reaped the benefits of association with a more developed civilization, but how does one get to enjoy those benefits if one lacks a sense of belonging, at home?

The seventh and last of our spatial metaphors is, By their fruits ye shall know them, not by their roots. The first part of the phrase is Biblical 
(Matthew 7:20) while the second part is a poetic addition. The statement is certainly a materialist interpretation of belonging and would be a perfect motto for the New Zealand education system. It is a "get-up-and-go" philosophy based on a kind of crude, meritocratic principle where the main problem is to address the liberal, distributive justice notion of how to share the fruits of one's labour without too much deliberation over questions like, why those fruits and not others, and why the egalitarian principle of distribution rather than some other.

The variety of ways of using spatial metaphors and the realities they encompass are clearly illustrated in the examples portrayed. The person from "the wopwops" (1) is being both romantic and disingenuous and probably living in changed circumstances. Those who make up the diaspora (2 and probably 7 ) share a "get real" pragmatism with those who choose to move beyond the limitations of geography and genealogy (6), yet both (2) and (7) are trying to get away from something just as much as they are seeking something new. Burns' chauvinism (3) is equalled by the sentiments expressed in the whakatauki (5). And who is not familiar with the biological determinism inherent in the hierarchy of God, the squire, and the rest of us (4)?

An elegant quote from that wonderful book by New Zealand environmentalist Geoff Park summarises the point I want to make about the relationship between the politics of identity and the politics of location. In his view: "How we inhabit a place can be the most telling expression of how we sense its worth, our intention for it and our connection with it" (1996, p. 31)

I think Park is correct again in his judgement that "the mountains" - and we could add rivers, lakes, streams and beaches - "not the plains, are the location of New Zealanders' passion for the natural world". Yet it is true, that most of us by far are what he calls, "coastal dwellers, edge-of-the-land people or plains people" (p. 11). The places where we spend most of our lives are the places most vulnerable to human destruction because we see them everyday and find it troublesome to evaluate the changing reality most familiar to us.

A final point about spatial metaphors is that for some people, for example, Māori and other indigenous peoples, the notion of metaphor is quite incorrect; they are in fact "spatial realities". In recent years Māori authors have begun listing their tribal affiliations after their name on papers, articles, books, film reviews, etc. Mason Durie (Rangitāne, Ngāti Kauwhata, Ngāti Raukawa) and Hirini Mead (Ngāti Awa, Ng àti T ūwharetoa, Tühourangi) are two contemporary examples. The authors are not having an identity crisis nor have they lost track of who they are or where they come from. The tribal affiliations are about formalising connections despite the multiplicity of forces aimed at fractionating or atomising one's existence to the priority of the individual. The affirmation of the self-collective, in the form of the tribe, survives along with the institution of the marae and the resurgence of Māori language and custom. These four artifacts (iwi, marae, te reo, tikanga) are unquestionably pillars of Māori survival into the twenty-first century.

A third short story introduces us to pepeha, which I am using as another metaphor to illustrate what O'Sullivan refers to as a "cosmological identification" (1999, p. 229).

\section{Theme 3: He Pepeha - A Metaphysical Basis for Critical Inquiry ${ }^{11}$ Short Story C}

Māori tradition obliges its descendants to begin every formal association which brings different groups of people together to greet each other and address the questions "Who am I?", "Where am I?", "What is this place about?", "Whose place is it?", "How do we fit into it?", and "What are we doing here?" Māori have traditionally welcomed strangers with what the French post-structuralist philosopher Jacques Derrida calls the "unconditional law of hospitality" (Māori call this ceremonial welcome a powhiri). He describes this as "a law which tells or invites us, or gives us the order or injunction to welcome anyone, any other one, without checking at the border who he or she is, what his or her nationality is, it's a way of being open to whoever comes" (Simmons \& Worth, 2001, p. 27).

The pepeha is how the speakers (or kaikorrero) introduce themselves at a powhiri. What is important is that the speaker facilitates connection through location and temporal signifiers (mountains, rivers, tribes, ancestors, etc.) to others present. It is those that one whakapapa to (that is, one makes genealogical links to) that were here earlier, that provide the depth and significance to one's presence, rather than simply the self.

The pepeha invokes at least three spatial metaphors: firstly, of "connectedness" or whakapapa; secondly, of "inside-outside" or rights or the lack of them, that is, türangawaewae; and thirdly, of "grounding" or responsibilities and obligations, which is part of the meaning of kaitiakitanga. The metaphor of the pepeha has multiple levels of understanding, which signals to those who understand the Māori language: (a) who I am; and (b) where I come from. ${ }^{12}$ 
When we hear a pepeha a number of important facts are revealed. For example, Maungakawa will not be known by many of you and unless you are familiar with the territory, neither will you know the Waitoa River which runs through the centre of the North Island, connects with the Piako River and exits at Hauraki. These features of the landscape reveal some of the boundary markers of my own identity. $N g \bar{a} t i$ Hauãis one of the confederation of Tainui tribes and is situated in the midst of some of the most productive land to be found anywhere in the world and includes the colonial settlements of Hamilton, Morrinsville, Matamata and Cambridge. My hāpu is Ngāti Te Oro close to the small village named Waharoa. For those who know tribal leadership will recognise in the pepeha the name of one of the fiercest warriors of his day (Te Waharoa) who was also the father of one of the greatest statesmen of his time (Wiremu Tamihana Tarapipipi). Those who know tribal histories and whakapapa will confirm that Tākaha is descended from Motai and is a Ngāti Raukawa connection.

Without taking this any further, kaitiakitanga and whakapapa are now, at least, partially explained. The fact that the pepeha is in the Māori language and only some of you will understand it, invokes, necessarily the "insider-outsider" or türangawaewae meaning. Those who do not understand Māori but would like to know what was said, are caught up in a politics which is dependent on the good-will of the speaker or others who know the Māori language for a translation, which, of course, is an interpretation of what was said and not what was actually said. Politics and human relationships, whether with other humans, with aggregates of other humans, or with aspects of the landscape, are inescapable. That is one reason of several why the powhiri is a relevant, appropriate and valid practice for all schools throughout New Zealand, despite an earlier Minister of Education's outburst about the time taken on powhiri in some schools. How the powhiri is practised is another question. Those schools that demonstrate their mana in knowing their place, as well as showing respect for those who represent other places and peoples, are to be encouraged, I would have thought. Every school and its community should at lest seriously consider when it was appropriate to powhiri, the format it should follow, who should be present, who should be responsible for what actions, and most importantly, how the ceremony of the powhiri was consistent with other school rituals like assemblies, prize-givings, parent evenings, and suchlike.

\section{Theme 4: A Rationale}

Despite the impressive developments that have occurred in Māori education over the last two decades (especially in the Mãori immersion field) a great deal more work needs to be done within the education system as a whole for it to be a fair and just system for all. The assumptions underlying this article are simple to state, but it is perplexing to realise that we know so little about them. The first, is that teachers are generally poorly informed about the socio-cultural backgrounds of their students, and the second is, we don't know what difference it would make if they were knowledgeable. ${ }^{13}$

Since the incorporation of te kohanga reo (TKR), kura kaupapa Māori (KKM), wharekura (WK), wānanga, and the kaupapa Māori philosophy these institutional forms embody, some things have definitely been changing in Māori education. The experience of "changing" has been characterised by a high output of energy from a group of academics, bureaucrats and teachers working in the interests of Māori learners and the ongoing reproduction of Māori culture. At the non-formal level a deeply committed and dedicated group of matua (parents), whanau (families) and kaumatua (elders) have also been heavily involved in the implementation of these organisations. The focus has been three-dimensional: revitalise te reo (Māori language), institute the kaupapa (Māori values and practices), and formalise the appropriate institutional arrangements for delivering the language and practices, namely, TKR, KKM, etc. The fact that public doubts about the wisdom and efficacy of the kaupapa Māori philosophy, policy, and practice are virtually non-existent ${ }^{14}$ suggest at least three things. First, that Māori education is serving the interests of Māori and should be left in the hands of those "who know best". Second, that what happens in Māori education is of little or no concern to mainstream education. Third, that searching for "middle-ground" or "over-lapping spaces" between Māori and mainstream education is an exercise in futility because of the asymmetrical power relations that exist between Māori and Pākehā. Put another way, the power of veto will always be exercised so that compromises will be one-sided in favour of the dominant group. A fourth reason for the relative absence of critique of the kaupapa Māori agenda might be that a general level of ignorance about "things Māori" makes it difficult for opposition to offer a coherent critique.

Despite the warning of veto just mentioned I want to highlight a concern for an "over-lapping" dimension that is central for any education to be labeled Māori. It also happens to be of critical concern 
to mainstream education, even though the level of consciousness with regard to it remains relatively muted and peripheral compared with the general Māori awareness of it. I refer, of course, to the theory and practice of place-based education (PBE).

My argument is that PBE is encapsulated in some essential way in every educational initiative that Māori have supported from before the establishment of the Native Schools Act of 1867 right through to the current kaupapa Māori agenda (Penetito, 2003). Literacy may have been the "raison d'être" of the Mission Day schools of the 1840s, while religious and industrial studies were central features of the curriculum of independent Māori Village schools of the late 1860s. However, Māori have always searched for ways to enhance their lives, without having to forfeit the "essence" of their traditional way of life, or limiting the choices available to them.

\section{Transforming the Unhappy Experience of Mainstream Schooling}

There is some evidence that Māori learners have made important gains over the last 20 years and I feel privileged to have been a part of those gains, but I think it is important to realise we have just begun. For the majority of Māori students, no matter where they are, formal education remains a frustrating and unhappy experience. Some of the recent research reports coming out of the Ministry of Education (Bishop et al., 2001, 2003) are an important reminder of how easy it is to delude ourselves of the progress being made. When expansive literacy, assessment, Māori language and professional development policies and programmes capture the attention of those involved in the everyday life of what goes on in schools, it is sobering to be reminded that in the eyes of Māori students, the most important influence on their educational achievement is the face-to-face relationships and interactions they have with their teachers. And from the teachers' point of view, the most important influences on the educational achievement of Māori students are the students themselves, their families or systemic constraints (2003, pp. 1-2). Not much seems to have changed. Forty years on from the Report of the Commission on Education (Currie Commission) we are still making the same excuses that lead to familiar consequences:

In the Māori pupil lies the greatest reservoir of unused talent in the population. The benefit that could finally accrue in the field of race relations, if the Māori could play the important part in all areas of the community that his numbers warrant, needs no emphasising. (1962, p. 414)
The common experience of Māori in mainstream schooling is replicated among other indigenous peoples around the world. We know that Māori learners, like all other learners, like to see themselves reflected in most aspects of the schooling experience, but what we do not know are answers to questions like the significance of the knowledge teachers have of locality, community, ecology and history, ${ }^{15}$ that is, social knowledge, and not just the knowledge they have of individuals, curriculum areas and pedagogy. John Watson made the point more than 40 years ago.

Not in New Zealand or anywhere else does there appear to have been a systematic, carefully-disciplined effort to test whether a teacher's knowledge of the local scene or his participation in it, has any significant effect upon his interest or capacity to integrate this knowledge into the scholastic work of his classroom, or into the emotional toning of his relationships with pupils. $(1967$, p. 40)

\section{Theme 5: Why "Place-based" Education?}

PBE offers a way out of this predicament. At its most basic, the objective of PBE is to develop in learners a love of their environment, of the place where they are living, of its social history, of the bio-diversity that exists there, and of the way in which people have responded and continue to respond to the natural and social environments. PBE has emerged as the result of four ubiquitous concerns: a form of detachment that people acquire as a result of familiarity with place; the need to overcome detachment by developing a consciousness of the environment; the homogenisation of cultures and communities in the interests of egalitarianism and efficiency; and the way in which local history is either ignored or presented disconnected from meaningful contexts. These concerns are outlined below.

\section{Separation from locality}

Talking about the environment usually raises thoughts in people's heads about rivers and lakes, mountains and streams, about pollution and conservation, biodiversity, global warming, and ozone layers. These are all part of a PBE but far too remote and abstract for what I have in mind.

Many years ago David Orr wrote:

If today is a typical day on planet Earth, we will lose 116 square miles of rainforest, or about an acre a second. We will lose another 72 square miles to encroaching deserts, as a result of human 
mismanagement and overpopulation. We will lose 40 to 100 species, and no one knows whether the number is 40 or 100 . Today the human population will increase by 250,000 . And today we will add 2,700 tons of chlorofluorocarbons to the atmosphere and 15 million tons of carbon. Tonight the earth will be a little hotter, its water more acidic, and the fabric of life more threadbare. (1991, p. 1)

Most people recognise the folly in ignoring warnings from informed environmental scientists like David Orr. Yet as the irrational creatures we often are, attributing urgency to something that appears remote in time and place generates curiosity rather than fear. The average New Zealander is easily persuaded to believe the propaganda of a "clean green New Zealand". After all, the thousands of tourists who tell us how beautiful our scenery is, who congratulate us for keeping our environments pollution-free and pristine can't all be wrong until one is reminded about Short Story $\boldsymbol{B}$ and the Waiwhetū Stream.

On the government's biodiversity website ${ }^{16}$ we are given another sober message:

Although New Zealand was one of the last places on earth to be settled by humans, it has one of the worst records of native biodiversity loss. Fire, land clearance, over-exploitation of resources, and introduced plants and animals have had a cumulative effect on native biodiversity. As a result dozens of species have become extinct and an increasing number are now threatened with extinction.

When one lives in a small country with only four million people, where it is relatively easy to go to beaches, forests, rivers, lakes and mountains, where the sunshine is bright, clean water is not too difficult to find, and the air is mostly pollution free, it is easy to be complacent about the environment at the day-to-day level.

\section{Ecological consciousness}

An important reason for focusing on a PBE then is so that we are better informed about our physical environment whether local, national or global. It is about developing an ecological consciousness and the understanding required to maintain sustainable communities. It is reasonable to assume that all education is in one sense environmental education. It doesn't make sense to talk about an education outside of that environmental context. None of this is new, and many topics in what has been taught as ecological studies, environmental studies, community studies and suchlike have been the forebears of PBE.
The nature of the relationship between organisms and environments has exercised the minds of people for centuries. As we battle the negative side of modernity, we are constantly being reminded of the debate about human beings and the environments we share. In New Zealand, the heat generated over the Government proposal regarding the "foreshore and seabed" and who owns it is one of the more recent manifestations of this debate. "Ginger groups" exist to remind us of the need to "Save the Environment" from the excesses of human destruction while concerns about the "balance of nature" are always presented to us as a fragile relationship. Both Pākehā and Māori buy into these arguments as though the environment exists outside the organisms that live within it; as though everything in nature is in balance and harmony until organisms come along like humans who, with typical greed and folly upset the balance. One of the world's leading geneticists, R. C. Lewontin tells us that

... there is nothing in our knowledge of the world to suggest there is

any particular balance or harmony. The physical and biological worlds since the beginning of the earth (3-4 billion years ago) have

been in a constant state of flux and change. (p. 118)

\section{Connecting culture with community}

Another characteristic of PBE, according to the Alaskan Upiak elder and educationist, Oscar Kawagley (2003) places an emphasis on teaching through rather than about culture. He argues that PBE utilises the local context and culture as the primary lens for the conveyance of all academic subject matter. In this context, the culture being referred to is that which is embedded in the community. Kawagley's work revolves mainly around improving education for Native children through a return to indigenous ways of knowing and doing ${ }^{17}$ and in that sense reflects what has occurred in Māori education in kohanga reo and kura kaupapa Māori developments. Within virtually any modern social environment the cultures and communities are likely to be multiple and diverse. PBE is rooted in what is local and therefore unique to a place.

A comment from The Appalachian Rural Education Network (2003) maintains:

The community provides the context for learning, student work focuses on community needs and interests, and community members serve as resources and partners in every aspect of teaching and learning.

I will expand this idea later in a discussion about a pedagogy for a PBE. 


\section{Breathing life into history}

The stereotypical attitude to the passage of history, according to the "ordinary Kiwi bloke", is that Māori are preoccupied with the past while Pākehā are preoccupied with the future. The Māori is said to worship his ancestors and the materialist Pākehā his consumer goods. When the war-like Māori descended on Aotearoa in a Great Fleet the peaceful Moriori were already resident and were killed, inter-married and/or driven out to the Chatham Islands. When the racially superior and more technologically advanced Europeans arrived on these shores they replaced the Māori in a similar way to that in which the Māori replaced the Moriori. This is the law of the "survival of the fittest", it is the "natural order of things" so we are led to believe. An article by the prominent New Zealand historian, James Belich (1997) discusses some of the well known myths and history that contribute to the collective identities of Māori and Pākehā. His work, along with that of other historians prominent in the reinterpretation of New Zealand history, ${ }^{18}$ features importantly as a counter-balance to the condition of historical amnesia, a learned forgetting, which is so deeply embedded in the way New Zealand history struggles to survive within the education system (Beer, 1986). The history I learned at primary school referred to at the beginning of this article has always been important to me because I learned it at school. It is only many years later when I learned a great deal more about Te Waharoa, Wiremu Tamihana Tarapipipi, Firth, the village of Waharoa, the dairy factory, Ngāti Hauā, and what I believe are the reasons teachers generally steer away from teaching local history that I begin to know and understand something of that place called Waharoa. As David Orr reminds us, "We cannot say that we know something until we understand the effects of this knowledge on real people and their communities" (1991, p. 5).

\section{Theme 6: A Pedagogy for Place-based Education}

This part of the discussion is really difficult. Given a preference, I tend to opt for "up-front", "in-your-face", "realist", and "materialist" approaches to theorising because it is easier than transcendental approaches. However, the more I have read about indigenous education and PBE, the more I have found myself having to integrate what Catherine Benland and Kuni Jenkins refer to in the Report of The Royal Commission on Social Policy (1988) as "The S-Factor" and "Te Hono ki Wairua" respectively.
There are several deep cultural assumptions that provide the conceptual and moral legitimacy behind the pedagogic practice commonly seen in classrooms throughout New Zealand. It tends to be egocentric (individualist), constructivist (participation of the learner in meaning-making), process-oriented, literacy-oriented, and motivated by linear recipes for progress. It is generally understood that teaching and learning is, to use a term from Bowers (2001, p. 183), a "mediated relationship" which I take to be synonymous with the "scaffolding" idea. According to Bowers (p. 186), "the teacher mediates how students experience and understand the aspects of culture that constitute the content of the curriculum." If the deep cultural assumptions are different from those espoused as the norm then the pedagogy will also be different.

A pedagogy, consistent with indigenous assumptions, needs to be based on at least three key propositions:

(a) For indigenous peoples, a sense of place is a fundamental human need;

(b) Indigenous peoples formalise the relationship between themselves and their environments as co-habitors; and

(c) A pedagogy capable of embodying ways of knowing and being cannot be sustained without some sense of consciousness that encompasses, in Māori terms, wānanga which is a conscious union of mind and spirit.

This pedagogic theme is too complex to be fully discussed here, but it does need to be addressed rather than omitted altogether. In this respect, the geneticist Lewontin quotes Simone de Beauvoir's clever but deep aphorism,

a human being is "l'être don't l'être est de n'être pas" - the being whose essence is in not having an essence (1993, p. 123).

To the indigenous mind, this absence of the human spirit, the mauri and wairua, makes no sense. Māori can see how this might eventuate in Western thinking with its Enlightenment legacy of prioritising the individual, along with the emergence of the rational world view, the dominant image of the machine, and the rise of the scientific revolution. But at what cost? The Enlightenment ideals imported into this country by the early settlers from Britain engulfed the people native to this land, with their particular cosmological identification articulated through the image of Papatuanuku (Earth Mother) and the land itself. The pattern 
was repeated among most of the indigenous peoples of the world. Whether the pre-eminent metaphor was the medicine wheel, the sacred tree, or Papatuanuku, each was designed to convey life processes as a seamless whole of symbiotic relationships, yet could not be accepted by the West as being merely different but had to be denigrated as myth and cast out as primordial. In Māori terms Papatuanuku is the nurturing mother earth. In his work with educationalists throughout the country in the 1970s and '80s, the Tuhoe elder, John Rangihau, used the metaphor of Māoritanga (the qualities of being natural to this place) to convey the same message of connectedness, inter-relatedness, and the sense of place as a fundamental human need. This connection between the people and the land/environment seems to pose real problems for those who need to espouse and practice the commodification of the landscape. The problem is that neither the former "holistic" view of the world nor the latter "commodified" view is satisfactory for the twenty-first century. A negotiated relationship between the two is imperative but not unproblematic. Park (1996) writes that, "Europeans have always been unsettled by New Zealand's landscape" (p. 310), preferring to think of it as "primeval waste awaiting cultivation" (p. 311), and where a need for conservation was agreed, "to set nature aside as large tracts of land in a state of imagined innocence- national parks and other 'reserves'" (p. 317). Replace "New Zealand's landscape" with Māori, and kaupapa Māori schools in the place of "national parks and other reserves" and one almost has a parallel scenario. Alan Webster, in his Spiral of Values, talks about "vision-consciousness and integral thinking" (2001, p. 225). He suggests that encouraging progress toward "vision-consciousness" might be worthwhile for all of us, instead of adopting the materialistic grounds for according status currently practised. What is more, Webster sees Māori as a culture poised to leap into "vision consciousness". The difference between what he is saying and what I am proposing is that progress does not have to depend on deciding between vision-consciousness or materialism; there is a place for "either" and "both".

This brings me to the seventh and final theme of this article.

\section{Theme 7: Research in Place-Based Education - A Summary}

In a study of how some schools produce high literacy levels at Year 3, Warwick Elley summarises his feelings about the research findings in these words: "It has been exhilarating for me to see so many talented, committed teachers, on top of their jobs and enjoying what they do" (2004, p. 5). A closer examination of the research reveals a not-toosurprising list of reasons why the teachers described are successful with a cross-section of New Zealand children: the students are heavily involved in a balanced programme; the teachers see themselves as generating in children a "lasting interest" in the programme; the teachers avail themselves of targeted training in the programme, demonstrating a commitment beyond the normal requirements; and the teacher is both enthusiastic about the programme, as well as being knowledgeable about her students.

I loved reading it. If only such actions could be replicated in other equally critical areas of education. The role research plays in uplifting, in reassuring, in providing support, and in giving guidance is as much a necessity in gauging effective reading programmes as it is in helping to decide the optimum path in place-based education initiatives.

The suggested areas of research identified in the text have been framed within two broad areas: firstly, "how to decide what differences matter"; and secondly, "how to make a difference." The first area covers matters of knowledge (curriculum), practice (pedagogy), location (social geography), and decision making (policy); the second looks mainly at community participation, ecological and social justice issues.

\section{How to decide what differences matter}

How to decide what differences matter directs our attention to what Harvey $(2000$, pp. 16, 242) calls a "relational dialectic" that can either be resolved as a "creative tension" or a "destructive and immobilising force". In Māori education, we know a great deal more about the negative side of the relational dialectic and nowhere near enough about the creative tension that exists as potential. PBE can facilitate historical and contemporary discussions that are dominated by mainstream perspectives and reified by a hegemonic process that poses a severe constraint on the Māori capacity to deconstruct and reconstruct a more realistic and optimistic Māori culture. Seven focused research questions are suggested as beginning points:

- What do Pākehā New Zealanders know about where they originate and/or where they live and what effect does this have on how they perceive themselves and others?

- Students from homes that maintain cultural traditions are a valuable resource for teachers and other students in PBE (Bowers, 2001, 
p. 183). What do we know about these students and how are they perceived in education?

- Given the popularity of the practice of pepeha among kaupapa Māori pupils, how familiar are they with the actual discrete landscape features mentioned in the pepeha; e.g, do they know where their mountains are? Have they visited them?

- What do teachers know about the communities that serve the schools they teach in?

- Does teacher knowledge about the communities that serve the schools they teach in make any difference to student learning?

- Assuming that teacher knowledge about the communities that serve the schools they teach in makes a difference to student learning, what sorts of knowledge are the most valuable? Why?

- Since a knowledge base is only one of several critical factors in the teacher-student-parent-community complex, what do we know about the influences on the teacher's pedagogy, assessment practices, etc., as a result of her/his knowledge of the community?

\section{How to make a difference}

There seems little doubt that difference is the socio-cultural transformation Māori are determined to pursue (Watkin, 2004; Webster, 2001). Instead of understanding that individualism always exists in relation to collectivism, that universalism is always internalised and implicated in particularism, and that culture and structure are dependent variables, what we learn is that not only are they different but that they are offered as oppositional. Viewed in dialectical terms, the creative tension for Māori, for example, between individualism and collectivism is always part of present consciousness and neither can ever be taken for granted. Where one's mana ake (unique individualism) is encouraged to develop, rangatiratanga (self-determination) for the collective identity is also facilitated. One cannot fully develop without the other in a relational totality. O'Sullivan writes, "the basic idea behind the person as a relational totality is that there is no sense of the person without the sense of the presence of community" $(1999$, p. 225). The saying in Māori is, "Ki te kore te iwi, e kore koe i kiia - he tangata" (without the people you are diminished, you are nobody). This is a harsh judgement that fundamentalist Māori would like to hold to, but the world has moved on and so have the majority of Māori. Today, the saying is expressed more as a sentiment than as normative.

\section{Conclusion}

Throughout this article I have posed a series of questions that revolve around two issues to do with "identity" (who am I?) and "location" (where am I?). The questions are placed within a political context which asks not only who we are and where we are, but how we fit in, what the place means to us, and what we mean to the place. The discussions around these questions constitute the field of "place-based" education that has its beginnings in indigenous education, environmental and ecological studies, and community education, but is more than any one of these disciplines. It is argued that indigenous peoples, the Māori in New Zealand for example, already have a well-rehearsed traditional and historical affinity to PBE practices. If, within a mainstream education system, this well-rehearsed tradition advantages Māori and other indigenous peoples, then that has to be a first and should be applauded. However, as I have been arguing throughout this article, focusing on PBE is educationally and culturally beneficial for all students.

\section{Notes}

1. Under the title Theorising a 'Place-Based'Education this article was originally presented as a keynote address to the annual conference of the New Zealand Association for Research in Education (NZARE) in Wellington, November 2004. Slight modifications have been made to the original text to fit with publication requirements.

2. See for example Editorial. (2002). Indigenous education: Ways of knowing, thinking, and doing. McGill Journal of Education; Smith \& Williams, 1999; Churchill, 1992.

3. See Sobel, 2004; O'Sullivan, 1999.

4. See Bookchin, 1995; Biehl, 1997.

5. See Vitek \& Jackson (Eds.), 1996

6. See Tuan, 2003; Feld \& Basso (Eds.), 1996.

7. See Keith \& Pile (Eds.), 1993.

8. See Shiva, 1997.

9. In the Report from the Conference on Priorities in Multi-cultural Educational Research (1981) a similar sentiment was expressed. "Too much attention had been given to helping Māoris fit into a Pākehā world and measuring how well they succeeded" (p. 10).

10. Place-Based Education, downloaded on October 16, 2006 from: $<$ www.watershedschool.org/program/place-based.html $>$. 
11. David Harvey (1996, p. 2) argues that metaphysics in the traditional sense is about "the critical enquiry that allows for the free interplay of passions, emotions, rationality, and intellect rather than their restrictive compartmentalisation." Metaphysics is the branch of philosophy that deals with cosmological and ontological concerns.

12. Apart from the obvious cultural connection this introductory custom brings with it, personal biography carries no greater moral authority or authenticity over others who are content, for example, with the written biographical notes in conference proceedings or at the end of a book.

13. Keddie asks similar questions with regard to classroom knowledge-what knowledge teachers have of pupils, and what counts as knowledge to be made available and evaluated in the classroom (Keddie, p. 133).

14. Vercoe (1995) is one of the few published articles that challenges the KKM approach but basically it is in sympathy with the kaupapa Māori philosophy and practice. Dr Elizabeth Rata (2004) has made a direct challenge to the philosophy and practice as well as to those she sees as advocating something they accepted without question. I have not discussed aspects of her critique in this article but a formal response could be helpful.

15. The edited book of readings by Ward Churchill (1992) and the publication by Howard Adams (1995), both of whom are Native American Indians, offer interpretations on the plight of the Indian, discuss shortcomings in many analyses of the research, and indicate solutions to these problems.

16. New Zealand Biodiversity Strategy - Up the Creek (2004): $<$ www.biodiversity.govt.nz/kids $>$,

$<$ www.biodiversity.govt.nz/picture/biodiversity/state/index.html >.

17. See McGill Journal of Education, 2002, 37(3) which is devoted entirely to this topic of indigenous ways of knowing and doing.

18. See, for example, Sorrenson, 1987; Sharp, 1990; McHugh, 1997, Orange, 1987.

\section{References}

Adams, H. (1995). A tortured people: The politics of colonization. Penticton, British Columbia: Theytus Books Ltd.

Appalachian Rural Education Network. (2003). Encouraging Place-Based Learning < http://ruraledu.org/topics/placebased.htm>.

Belich, J. (1997). Myth, race, and identity in New Zealand. The New Zealand Journal of History, 31(1), 9-22.
Benland, C. (1988). The S-Factor: Taha Wairua. Royal Commission on Social Policy, Vol.III, Part 1 Future directions (pp. 451-468). Wellington, Royal Commission on Social Policy.

Biehl, J. (Ed.). (1997). The Murray Bookchin Reader. London: Cassell.

Bishop, R., Berryman, M., \& Richardson, C. (2001). Te toi huarewa: Effective teaching and learning strategies, and effective teaching materials for improving the reading and writing in te reo Māori of students aged 5 to 9 in Mãori-medium education. (Final Report to the Ministry of Education).Wellington: Ministry of Education.

Bishop, R., Berryman, M., Tiakiwai, S., \& Richardson, C. (2003). Te kotahitanga: The experiences of year 9 and 10 Māori students in mainstream classrooms. (Report to the Ministry of Education). Māori Education Research Institute (MERI), School of Education, University of Waikato, Hamilton and Poutama Pounamu Research and Development Centre (PPRDC), Tauranga.

Bookchin, M. (1995). Re-enchanting humanity: A defense of the human spirit against anti-humanism, misanthropy, mysticism, and primitivism. London: Cassell.

Bowers, C. A. (2001). Educating for eco-justice and community. Athens \& London: The University of Georgia Press.

Churchill, W. (Ed.). (1992). Marxism and native Americans (Third printing). Boston: South End Press.

Commission on Education in New Zealand. (1962). Report of the Commission on Education in New Zealand (The Currie Report). Wellington: Government Printer.

Department of Education. (1981). The Report from the Conference on Priorities in Multi-cultural Education. Wellington, Department of Education.

Elley, W. B. (2004). Effective reading programmes in the junior school. set 1, Celebrating 30 Years. Wellington: New Zealand Council for Educational Research, pp. 2-6.

Feld, S., \& Basso, K. H. (Eds.). (1996). Senses of place. Santa Fe, New Mexico: School of American Research Press.

Gilroy, P. (1993). Small acts: Thoughts on the politics of black cultures. London: Serpent's Tail.

Harvey, D. (1996). Justice, nature \& the geography of difference. Cambridge, MA: Blackwell Publishers. 
Harvey, D. (2000). Spaces of hope. Los Angeles: University of California Press, Berkeley.

Jenkins, Kuni. (1988). Te Hono ki Wairua. Royal Commission on Social Policy, Vol.III, Part 1, Future directions (pp. 491-496). Wellington: Royal Commission on Social Policy.

Kawagley, O. (2003). Fostering native schools and culture. $<$ http://ruraledu.org/topics/native.htm >.

Keddie, N. (1975). Classroom knowledge. In M. F. D. Young (Ed.). Knowledge and control: New directions for the sociology of education (pp. 133-160). London: Collier-Macmillan Publishers.

Keith, M., \& Pile, S. (Eds.). (1993). Place and the politics of identity. London \& New York: Routledge.

Lewontin, R. C. (1993). The doctrine of DNA: Biology as ideology. London: Penguin Books.

Low-Beer, A. (1986). The eclipse of history in New Zealand schools. New Zealand Journal of Educational Studies, 21(2), 113-122.

McHugh, P. G. (1997). Law, history and the Treaty of Waitangi. The New Zealand Journal of History, 31(1), 38-57.

Mead, H., \& Grove, N. (2001) Ngā peppeha a ngà tipuna: The sayings of the ancestors. Wellington: Victoria University Press.

Orange, C. (1987). The Treaty of Waitangi. Port Nicholson Press: Allen \& Unwin

Orr, D.(1991). What is education for? $<$ www.context.org/ICLIB/IC27/Orr.htm>

O'Sullivan, E. (1999). Transformative learning: Educational vision for the 21st century. London: Zed Books.

Park, G. (1996). NgāUruora: The groves of life: Ecology and history in a New Zealand landscape. Wellington: Victoria University Press.

Patterson, C. (2004, July 28). Polluted stream "too warm to fish". The Dominion Post, p. A8.

Penetito, W. (2003). Turangawaewae: A place where one can stand The context for developments in Māori education. In K. Sanga, C. Chu, C. Hall \& L. Crowl (Eds.). (2005). Re-thinking aid relationships in Pacific education (pp. 348-374). He Parekereke: Institute for Research and Development in Māori and Pacific Education, Victoria University of Wellington and Institute of Education, University of the South Pacific, Suva.
Place-Based Education. (2006). Retrieved on October 16, 2006 from $<$ www.watershedschool.org/program/place-based.html $>$.

Postman, N., \& Weingartner, C. (1971). Teaching as a subversive activity. Middlesex, England: Penguin Books, in association with Pitman Publishing.

Rata, E. (2004, July). Ethnic ideologies in New Zealand education: What's wrong with Kaupapa Māori? Paper presented to Teacher Education Forum of Aotearoa New Zealand Conference (TEFANZ), Auckland College of Education.

Sharp, A. (1990). Justice and the Māori: Māori claims in New Zealand political argument in the 1980s. Auckland: Oxford University Press.

Shiva, Vandana. (1997). Monocultures of the mind: Perspectives on biodiversity and biotechnology. London \& New York: Zen Books Ltd.

Simmons, L., \& Worth, H. (Eds.). (2001). Derrida downunder. Palmerston North: Dunmore Press.

Sobel, D. (2004). Place-based education: Connecting classrooms and communities. Great Barrington, MA: The Orion Society.

Sorrenson, M. P. K. (1987). Towards a radical reinterpretation of New Zealand history: The role of the Waitangi Tribunal. The New Zealand Journal of History, 21(1), 173-188.

Smith, G. A., \& Williams, D. R. (Eds.). (1999). Ecological education in action: On weaving, culture, and the environment. Albany, NY: State University of New York Press.

Tuan, Y. (2003). Space and place: The perspective of experience. Minneapolis/London: University of Minnesota Press.

Vercoe, A. (1995). Resistance in Māori education: A critique of kura kaupapa Māori. Waikato Journal of Education, 1, 119-135.

Vitek, W., \& Jackson, W. (Eds.). (1996). Rooted in the land. New Haven \& London: Yale University Press.

Watkin, T. (2004, March 20). Moving on up - A people's progress: 30 years of the Māori renaissance. The New Zealand Listener, pp. 16-20.

Watson, J. E. (1967). Horizons of unknown power: Some issues of Māori schooling. Wellington: New Zealand Council for Educational Research.

Webster, A. (2001). Spiral of values: The flow from survival values to global consciousness. An interpretation of the New Zealand study of values. Hawera: Alpha Publications. 
Willinsky, J. (1998). Learning to divide the world: Education at Empire's end. Minneapolis, MN: University of Minnesota Press.

Your Voice (2004, September 22). Cleaning up our act. The Dominion Post, p. B7.

\section{The author}

Dr Wally Penetito is Professor of Māori Education, Te Kura Māori and Co-Director of He Parekereke: Institute for Research and Development in Māori and Pacific Education, at the College of Education, Victoria University of Wellington. 